\title{
Development of Naturalist Intelligence of Children in Kindergarten
}

\author{
Nurhafizah Nurhafizah \\ Departement of Early Childhood Education \\ Universitas Negeri Padang, Indonesia \\ nurhafizah@fip.unp.ac.id
}

\begin{abstract}
This research aims to see the development of child naturalist intelligence in kindergarten, especially in Koto Tangahsubdistrict, Padang. This area is an agro tourism and has a very good natural view to serve as a medium of learning. The research method used is a qualitative approach, which is the result of initial observation in strengthening the research problem using technique triangulation. Based on the results of the initial observation it was found that three schools of Kindergarten that have been observed, It can be concluded that the development of naturalist intelligence is not in maximum level. Children are more likely to learn in classical activities. From observations and interviews that conducted, children almost never learning occurs outside the classroom, as well as utilization of the natural surroundings such as plants and animals do not even serve as a source of learning. Observation of indicators has not seemed to development naturalist significantly in these samples.
\end{abstract}

Keywords--children's naturalist intelligence; kindergarten.

\section{INTRODUCTION}

Education is a basic human need that must be met, therefore the government regulates this in such a way, both in the rule of law and the policies so that every individual is entitled and received education. Therefore education should be done as early as possible starting from early childhood education because at this time is a golden period for child development, golden period which is meant is a very critical period for children, developments gained at this time very influential on child development at further developments.Early childhood education provides an opportunity for children to develop various aspects of abilities that include cognitive, language, social, emotional, physical and motor.

Cognitive development is the development associated with intelligence intelligence. Intelligence Intelligence is the ability to solve problems. [1]; [2]Suggests there are nine kinds of intelligence that needs to be developed, one of which is naturalist intelligence.

Naturalist intelligence is concerned with sensitivity in appreciating nature and the environment. The development of a child is not only influenced by heredity but also the environment around the child. The development of natur[3].

This is in line with the opinion of [4] that naturalist intelligence is the ability to recognize, differentiate, reveal, and make criteria to what we encounter in nature and environment. In other words, the human ability to recognize plants, animals and other parts of the universe.

Naturalist intelligence is the sensitivity to nature and its content (flora and fauna) and the ability to understand and appreciate the impacts of nature on self and the impact of one's own actions on nature [5]. This intelligence includes the ability to recognize and classify various kinds of flora and fauna and enjoy the fellowship with nature. This opinion is in line with Armstrong's [6] thought states that naturalist intelligence is defined as recognizing skills and categorize species, both flora and fauna, in the neighborhood and ability to process and utilize, and preserve it

Amstrong[7] also said that naturalist intelligence is important for survival today because so many aspects of the environment are threatened by the excesses of technology so that it takes people who have naturalist tendency to give way out of ecological problems so that the child's naturalist intelligence develops so that it can help protecting the environment. Given the importance of this naturalist intelligence, the concept of developing naturalist intelligence needs to be familiarized and embedded from an early age. Especially at this age of internalization of naturalist values will be very effectively absorbed and applied by children. Above this age the effectiveness is predicted to decrease and become less effective as children age. In addition, educators and parents can develop children's naturalist intelligence such as introducing plants, animals and other natural objects that exist around the child starting from the nearest.

Yazid (2012)[8] says that how to develop naturalist intelligence in children is to invite children to perform activities outside the home and school such as gardening, watering flowers, seeing insects, introducing the natural objects that exist around children such as stones, leaves or the name of various types of plants. According to [6] naturalist intelligence is related to the skills in recognizing and classifying flora and fauna in the environment and love of natural objects, animals, plants and also characterized by sensitivity to the forms of plants in the natural surroundings, such as leaves, various kinds of flowers, and also other objects such as rocks, sand and others. While the meaning of nature around according that concerns our concern for the surrounding environment that concerns the cleanliness, utilization of used materials from the former useless. Besides 
the natural meanings around that is interpreted by activities such as loving animals, maintaining plants and not littering and many more similar activities [9].

The child's naturalist intelligence at the age of 4-6 years appears in shape have started to have a sense of sensitivity to the surrounding environment, they already have have an interest in nature (by observing, engaging, looking at pictures, collecting plant or animal elements), caring for and maintaining animals or plants, documenting through images, and searching for information through asking, viewing impressions, and reading. [10].

The introduction of the environment both in the classroom and outside the class has not been given, even if there is very limited with the same method. Teacher have not utilized the surrounding environment, both animals, plants and events nature in the neighborhood around the school to serve as part of children's learning. The results of research [11] in classroom action research showed improvement of naturalist intelligence with field visit method. The results [12] that through the learning of natural materials disentra can develop the child's naturalist intelligence.

From the above findings can be seen that the development of naturalist intelligence is very important, especially the nature around as a medium because it will bring a pleasant impact in the process of life of a child to a more mature age and will become long-term memory. this is evidenced from some previous research results in several countries.

Adults who work in environmental education and/or protection often cite two types of experiences-playing innature as a child and having a family role model who highly valued the natural world-as influential for their own commitment. This attribution indicates the importance of nature play in childhood for developing a bond with the natural world and the value of both community and adult focus on youth connections with nature. In her interviews with 56 environmentalists in Norway and Kentucky, for example, found that nearly all adults in both countries recalled places they played as children or hiked as adolescents, and the vast majority of respondents also connected these experiences with memories of a special relative who "confirmed nature's value". Large-scale survey research conducted with adults in different countries also links positive environmental attitudes and behaviors with early nature experiences. [13].

Through their experiences in the natural world, children not only learn to enjoy their time outdoors but also prepare for creative and informed participation in society and in environmental preservation. Authentic participation by children, where they clearly understand what they are doing and why, is closely linked to development of environmental stewardship. These authentic nature experiences are critical for shaping life-long values, attitudes, and behavior patterns toward the natural environment [14] The practices may be pulling children out of the natural world, but results of research support the premise that time spent in nature with a caring adult facilitates children's understanding of and connection to the natural world.

\section{RESEARCH METHODOLOGY}

The research was conducted in three kindergartens in Koto Tangah sub-district, namely MayangTaurai Kindergarten, AisyiyahMurni Kindergarten and KairTangah Padang Kindergarten, each held in Kindergarten Group B.

The research was conducted in the form of preliminary observation before carrying out the experiment, in August 2017, which is about the development of naturalistic intelligence performed on the three kindergartens. This research uses descriptive qualitative method which aims to describe something of condition or phenomenon as it is through observation and interview, teacher as primary data source, and document of learning implementation and interview with child as secondary data. The data have been obtained then processed in a qualitative manner using triangulation technique with developed by Miles and Huberman[15].

\section{RESEARCH RESULTS}

Kindergarten where the first research is a kindergarten MayangTaurai consists of 34 people. The second kindergarten of TK AisyiyahMurni Padang. The total number of children is 130 people. Kind of kindergarten KhairaUmmahIkur Koto consists of 115 children.Based on the observations that have been done in three kindergartens in Koto TangahSubdistrict, Padang, by observing and interviewing principals and teachers who teach and see firsthand the activities of children, found the problem that the child's naturalist intelligence has not developed optimally because almost a child still shows lack of attention to the surrounding environment.

Seen by there are children who do not know objects that exist in the environment such as the type of plant, the names of flowers, but often found children. In addition, children are still less able to enjoy the nature around him that actually provides great potential as a means of learning.One reason is the absence of development of naturalist intelligence in the planning of teacher learning, still less varied learning methods used especially in learning that is directly related to nature. In the learning of teachers still tend to centralize learning to the achievement of academic results that are classical and indoor only. Teachers still often use the image media in learning rather than the original by looking or observing directly, when in fact it is easy to get it in the natural environment around the school.

From the interview results found that the development activities of naturalist intelligence in particular tend not to do. There seems to be a lack of understanding of the development of that intelligence and how it is developed. Teachers only do rigid activities in the classroom to pursue curriculum targets. No visible creativity of teachers in choosing the appropriate approach, method or media so as to develop the child's naturalist intelligence. There is no authentic activity as the 2013 curriculum demands that the child should be in direct contact, feel directly with what is learned, including in touch with the natural surroundings. Whereas the nature around is a very valuable medium for that purpose. 


\section{DISCUSSION}

Childhood is a very important sensitive period for the child's education during that time, forging will give a strong mark in the next child's life. Mistakes in developing children have long-term negative effects that are difficult to fix. According to Gardner says that virtually every child is an intelligent child. And according to Frobel in the Age, et.al has the view that children as individuals who in nature is good. While Freud reveals early age is a decisive period and greatly affect the development of life, and personality of a person[2] .

The goal to be achieved in early childhood education is to create a conducive environment and education, so that all the potentials in the child can develop optimally, and the implementation of early childhood education can help children develop various potentials both physical, emotional, social, and cognitive, [16]. As Psychologist Turner and Helmes in Heni say that Playing has considerable influence for children's social and personality development, play is a meaningful activity and help children connect with their environment [9].

Based on the analysis of obsevation data in MayangTaurai kindergarten, kindergarten AisyiyahMurni and kindergarten KhairoUmmah Padang, the development of naturalistic intelligence has not become an important activity in learning, even some teachers are not familiar with the term naturalistic intelligence. This is apparent from the planning made and the implementation of daily activities and from the method of learning both in kindergarten using group learning methods and in kindergarten using the center method, not one can describe the development of specific naturalistic intelligence.

Teachers tend to focus more academic and classical oriented activities that are of course not appropriate in the development of naturalistic intelligence that is more likely to be outdoor activities and related to the utilization of the surrounding nature as a medium of learning. this is due to lack of understanding, lack of referrals, lack of commitment, limited time, and so forth [17].

Outdoor activities can be done for example through a field trip method. The method of field trip is a method of learning that invites learners to a certain place to learn something related to the material being taught. The method of field trips is very well used with materials that involve children directly and are real-world in their environment. This is so that children can know and know more clearly and detail related to what is taught through the process of observation. the naturalist intelligence is the intelligence to love the beauty of nature through the introduction of the flora and fauna contained in the environment and also observe the natural phonemona and sensitivity or concern for the surrounding environment. By choosing the play method then the child's play needs can be fulfilled. And through the child can get a lot of information in developing its potential [18].

Parten said [19], viewing play activities as a means of socialization, is expected through play to provide opportunities for children to explore, discover, express feelings, create, and learn fun. In addition, play activities can help children know about themselves, with whom the child lives and the environment in which the child lives.Therefore the effort that can be done is to begin to introduce and bring the child closer to nature through the activities of the introduction directly. One way that can be done is to use the method of field trips, demonstrations and direct practice. With these methods children can express feelings, create and learn in a fun and natural environment as a medium.

\section{CONCLUSIONS}

Based on the results of research and discussion that has been described then it can be concluded that: (1) Planning made teachers have not shown that naturalistic intelligence has not become part of the learning activities. (2) In the implementation of learning activities development of naturalistic intelligence is not an important activity, it is only a distraction and incidental if there is usually without proper planning.From these conclusions it is suggested that (1) teachers need to make the development of naturalistic intelligence an important activity in learning to develop a more valuable child's ability by incorporating it into learning planning. (2) the implementation of the development of naturalistic intelligence is carried out by choosing the appropriate approach, method and media and make outdoor activities in the natural environment becomes the main element.

\section{References}

[1] H. Gardner, Multiple Intelligences. Jakarta: Daras Books, 2013.

[2] Lexy J. Moleong, "Teori dan Aplikasi Kecerdasan Jamak/Multiple Intelligence.," Pendidik. Anak Usia Dini, 2004.

[3] Nurhafizah, "The development of Naturalistic Intelligent in Early Childhood (Proceeding 3th International Conference of Early Childhood Education," 2015.

[4] Indragiri, Kecerdasan Optimal, Cara Ampuh Memaksimalkan Kecerdasan Anak. Yogyakarta: Star Books, 2014.

[5] Anita Lee, 101 Cara menumbuhkan Kecerdasan Anak. Jakarta: PT Elex Media Komputindo, 2003.

[6] T. Armstrong, Seven Kind Of Smart Menemukan dan Meningkatkan Kecerdasan Anda Berdasarkan Teori Multiple Intelligence. Jakarta: Gramedia, 2002.

[7] T. Amstrong, Setiap Anak Cerdas, Panduan Membantu Anak Belajar Memanfaatkan multiple intellegence-nya.(Translate). Jakarta: PT Gramedia Pustaka Utama., 2005.

[8] Y. Bustomi, Panduan lengkap PAUD melejitkan potensi anak. Bandung: Citra Publishing, 2012.

[9] S. \& M. F. Docket, Play and Pedagogy in Early Childhood-Bending The Rules. Sidney: Harcourt, 2000.

[10] T. Musfiroh, Cerdas Melalui Bermain (Cara Mengasah Multiple Intelligence Pada Anak Sejak Usia Dini). Jakarta: PT Grasindo, 2008.

[11] Y. Juniarti, “JURNA,” J. Pendidik. USIA DINI, vol. Volume 9, 2015.

[12] A. Saripudin, "Strategi Pengembangan Kecerdasan Naturalis Pada Anak Usia Dini," AWLADY J. Pendidik. Anak, vol. Vol. 3 No., 2017.

[13] D. F. Chawla, L., \& Cushing, "Education for strategic environmental behavior," Environ. Educ. Res., vol. 13(4)., pp. 437-452, 2007.

[14] R. Wilson, Nature and young children: Encouraging creative play and learning in natural environments, Second edi. New York: Routledge, 2012.

[15] L. J. Moleong, Metodologi Penelitian Kualitatif. Bandung: PT Remaja Rosdakarya, 2009.

[16] Depdiknas, Undang-Undang Nomor 20 tahun 2003 tentang Sistem Pendidikan Nasional. Jakarta: Depdiknas, 2004.

[17] E. G. Hurlock, Perkembangan Anak Jilid I (translate). Jakarta: 
Erlangga, 1997.

[18] N. Seefeldt, C. \& Barbour, Early chidhood education: An introduction (4th ed). Ohio: Merrill Publishing Company., 1998.

[19] A. Sudono, . Sumber Belajar dan Alat Permainan Untuk Pendidikan Anak Usia Dini. Jakarta: PT. Grasindo, 2003. 